RowatT, E. (1957). J. gen. Microbiol. 17, 279-296

\title{
Some Factors Affecting the Growth of Bordetella pertussis
}

\author{
By ELIZABETH ROWATT*
}

\author{
The Lister Institute of Preventive Medicine, Elstree, Hertfordshire
}

\begin{abstract}
SUMMARY : Bordetella pertussis incubated in liquid media is prevented from multiplying by autoclaved cysteine and is rapidly killed by another substance, possibly a peroxide. The inhibition by autoclaved cysteine is overcome by serum albumin and the inhibition by 'peroxide' is overcome by red blood corpuscles, haemin, or ferrous sulphate sterilized by filtration. In a medium containing casein hydrolysate and yeast extract, logarithmic growth may continue for $40-50 \mathrm{hr}$. at one rate and then may change to a slower rate which continues for a further 20-30 hr. before growth stops. The initial growth rate can be maintained throughout by adding high concentrations of whole blood. The yield of organisms is proportional to the concentration of glutamic acid up to $\mathbf{0 . 3} \%(\mathrm{w} / \mathrm{v})$. It is possible that growth at greater concentrations is stopped by the high pH value caused by the oxidation of glutamate. Omission of casein hydrolysate decreases the yield of bacteria. A larger yield is obtained by the use of a large inoculum of bacteria with adherent blood.
\end{abstract}

Until 1939, Bordetella pertussis could not be grown in liquid media unless blood or tissue extracts were added. In that year Hornibrook (1939) obtained growth in a casein hydrolysate medium containing starch and cysteine. Small inocula would not grow in this medium, and in the modified medium introduced by Cohen \& Wheeler (1946) the organism did not grow unless the initial inoculum was more than $10^{6}$ bacteria $/ \mathrm{ml}$. of medium. Cultures have been grown from 1000 or fewer organisms $/ \mathrm{ml}$. in casein hydrolysate previously treated with charcoal and fat solvents (Fisher, 1948) or with charcoal at different $\mathrm{pH}$ values (Jebb \& Tomlinson, 1955). Proom (1955) showed that colloidal sulphur and sulphides and heated cysteine are important inhibitors of the growth of $\boldsymbol{B}$. pertussis and when steps are taken to exclude these compounds small inocula will grow in Cohen \& Wheeler's medium (see Rowatt, 1955). Hornibrook (1940), Proom (1955) and Jebb \& Tomlinson (1955) all describe fairly simple defined media for the growth of $\boldsymbol{B}$. pertussis. All contain nicotinamide, glutamic acid and cysteine or cystine, but differ in the other components. These media giving slow, rather limited growth are inadequate for growing large quantities of bacteria for vaccines or metabolic studies.

To obtain good growth of bacteria three main conditions must be observed: growth must begin promptly; the logarithmic growth rate must be rapid and must be maintained throughout the growth period; and sufficient nutrients must be present to give a high final yield of viable organisms. Some of the substances and conditions necessary to give good growth of Bordetella pertussis are detailed below.

* Present address: Central Public Health Laboratory, Colindale Avenue, London, N.W. 9 . 


\section{METHODS}

Organisms. Virulent strains of Bordetella pertussis were obtained from public health laboratories and dried by the method of Greaves (1944) at the third subculture after isolation on Bordet-Gengou medium. The strain M2400, which was less easily adapted to blood agar than other strains, was used throughout the investigation; for the experiments reported here it was dried at the second subculture after mouse passage. These strains were maintained on BordetGengou (BG) medium W.H.O. report, 1953) and discarded at the fourteenth (48 hr.) subculture when another dried culture was opened. 'Pertussis A', obtained from Dr Pollock, was stored dried at the eighth subculture from the original isolation (see Pollock, 1947) and maintained on blood agar (BA, $5 \%$ $(v / v)$ defibrinated horse or human blood). The rest of the strains were maintained on digest agar plates (DA, a tryptic digest of horse meat) and dried cultures were opened when required. The strains of $\boldsymbol{B}$. parapertussis and $\boldsymbol{B}$. bronchiseptica were obtained from the National Collection of Type Cultures (NCTC). The phase IV strains of $B$. pertussis were: CN 2217, a strain derived from the phase I CN 1262 by the Wellcome Research Laboratories; NCTC 364, the original phase IV strain of Leslie \& Gardner (1931) acquired by the NCTC in 1920; G 154 E and G146 E obtained from Glaxo Laboratories Ltd. G 154 E contained a heat-stable antigen agglutinated by serum against the heat-stable antigen of phase $\mathrm{I} B$. pertussis. All cultures were incubated at $35^{\circ} \mathrm{C}$.

\section{Small-scale growth experiments}

Inocula for small-scale experiments were grown on BG plates for 24-48 hr. and suspended in phosphate buffered saline $(\mathrm{pH} \mathrm{7 \cdot 2)}$, diluted 1/1000, and $0.02 \mathrm{ml}$. was added to $20 \mathrm{ml}$. medium (total dilution $10^{-6}$ ). Expressed as numbers of viable bacteria/ml. medium, the inocula were between $10^{2}$ and $10^{4}$ equivalent to $10^{-6}-10^{-8} \mathrm{mg}$. dry wt. $/ \mathrm{ml}$.

Apparatus. Media (20 ml.) in $100 \mathrm{ml}$. Pyrex Erlenmeyer flasks capped with $30 \mathrm{ml}$. beakers were incubated at $35^{\circ}$ on a horizontal shaker (Kantorowicz, 1951). The same shelf of the shaker was always used. Glassware was cleaned in ethanolic potash followed by concentrated $\mathrm{HCl}$ with $\mathrm{NaNO}_{3}$ (flasks, test tubes and beakers) or by $2.5 \mathrm{~N}-\mathrm{HCl}$ (pipettes) and rinsed with glass-distilled water. Pipettes were plugged with cotton wool.

Media used contained the same ingredients as Cohen \& Wheeler's (1946) medium except in the details listed below:

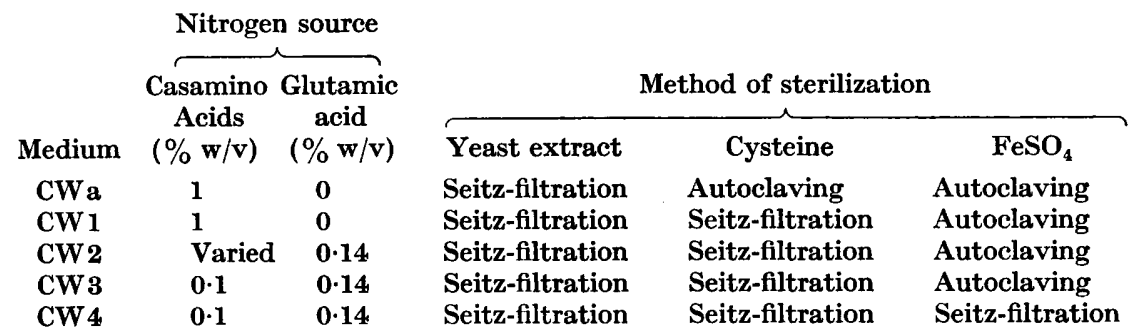


Yeast extract was an aqueous extract of fresh yeast (see Rowatt, 1955). Casamino Acids, unless otherwise specified, was Bacto-vitamin-free Casamino Acids (Difco). It was autoclaved in $10 \%(\mathrm{w} / \mathrm{v})$ solution at $120^{\circ}$ for $20 \mathrm{~min}$. before being autoclaved with the rest of the medium. $\mathrm{MgCl}_{2}$ was replaced by the equivalent quantity of $\mathrm{MgSO}_{4} \cdot 7 \mathrm{H}_{2} \mathrm{O}(0 \cdot 48 \mathrm{mg}$. $/ \mathrm{ml}$.).

Media were autoclaved in bulk and then dispensed into flasks. Amino acids were obtained from Roche Products Ltd. One sample of haemin was obtained from this firm, another was kindly supplied by Messrs L. Light and Co. Ltd. A recrystallized sample was given by Professor C. Rimington. Red blood cells were centrifuged from human blood, washed with saline and the packed cells lysed with distilled water. They were added aseptically to the autoclaved media. Oleic acid was purified from a commercial sample by low temperature crystallization (Smith, 1939).

\section{Large-scale growth experiments}

Inocula for large-scale experiments were grown on BG slopes in $6 \times 1$ in. test tubes for $\mathbf{2 4} \mathrm{hr}$. Approximately $3 \mathrm{ml} .1 \%$ (w/v) Casamino Acids ( $\mathrm{pH} 7$ ) were added to all of the tubes and then the bacteria were emulsified with a Pasteur pipette and the suspensions pooled and diluted such that $5 \mathrm{ml}$. could be added to each $500 \mathrm{ml}$. medium. Five to nine tubes were used for $5 \mathrm{l}$. medium, giving a concentration of approximately $10^{7}$ viable organisms $/ \mathrm{ml}$. medium.

Apparatus. Media (500 ml. unless otherwise stated) were autoclaved in penicillin flasks plugged with cotton wool and incubated as above. The most rapid rate of shaking was used except where otherwise stated. Glassware was cleaned with detergent in the routine washing up room and was not strictly grease-free.

Media were made as Cohen \& Wheeler's (1946) medium except that $\mathrm{MgSO}_{4}$ and yeast extract were used as above and Casamino Acids was replaced by a pancreatic hydrolysate of casein obtained from Benger Laboratories Ltd., Holmes Chapel. Cysteine and yeast extract were autoclaved with the rest of the medium unless otherwise stated. The media were:

\begin{tabular}{|c|c|c|c|c|c|}
\hline \multirow[b]{3}{*}{ Medium } & \multicolumn{2}{|c|}{ Nitrogen source } & & & \multirow{3}{*}{$\begin{array}{c}\text { Concn. of } \\
\text { cysteine } \\
\text { (mg./ml.) }\end{array}$} \\
\hline & \multirow{2}{*}{$\begin{array}{c}\text { Casein } \\
\text { hydrolysate } \\
(\% \mathrm{w} / \mathrm{v})\end{array}$} & \multirow{2}{*}{$\begin{array}{c}\text { Glutamic } \\
\text { acid } \\
(\% \mathbf{w} / \mathbf{v})\end{array}$} & \multicolumn{2}{|c|}{ Method of sterilization } & \\
\hline & & & Yeast extract & Cysteine & \\
\hline LS 1 & 1 & $0 \cdot 1$ & Autoclavin & Autoclaving & 0.03 \\
\hline LS2 & 1 & Varied & Autoclaving & Autoclaving & 0.03 \\
\hline LS3 & $\mathbf{0}$ & 0.5 & Autoclaving & Autoclaving & 0.03 \\
\hline LS4 & $\mathbf{0}$ & 0.5 & Autoclaving & Seitz-filtration & Varied \\
\hline
\end{tabular}

\section{Estimations}

Concentration of organisms. Viable counts were made by the method of Miles \& Misra (1938) on BG medium using $1 \%(\mathrm{w} / \mathrm{v}$ ) Casamino Acids as diluent. One flask was removed from the incubator for each sample. Concentration of suspensions of organisms was measured by a Gambrell photoelectric colorimeter and expressed as mg. dry weight/ml. (see Rowatt, 1955). 
Iron estimation. Iron was estimated with $\alpha \alpha^{\prime}$-dipyridyl by the modification of Thorp (1941).

Haemin estimation. Haemin was estimated by the method of Rimington (1942).

Other estimations were carried out as described previously (Rowatt, 1955).

\section{RESULTS}

\section{Effect of various conditions on the lag period}

Condition of the inoculum. In the experiments reported here the inoculum was adjusted to give a final concentration of $10^{2}-10^{3}$ viable organisms $/ \mathrm{ml}$. in the final growth medium. In the standard $\mathrm{CW} 1$ medium containing filtered cysteine, the lag phase lasted 5-17 hr. It was measured by finding the point of intersection of the logarithmic phase and a line drawn at the level of the initial inoculum. The differences in length of lag phase were partly due to age of inoculum because, although some $48 \mathrm{hr}$. inocula gave a lag period of less than $12 \mathrm{hr}$., none of the $24 \mathrm{hr}$. inocula showed lag periods of more than $12 \mathrm{hr}$. In this medium, the addition of lysed red blood cells shortened the lag phase in all experiments: in that shown in Fig. 1 the length of the lag period was halved.

Effect of autoclaved cysteine. Proom (1955) showed that colloidal sulphur and sulphides which are formed when cysteine is autoclaved inhibited the growth of Bordetella pertussis. Although Cohen \& Wheeler (1946) obtained growth of $\boldsymbol{B}$. pertussis from large inocula in the presence of autoclaved cysteine, with a small inoculum $\left(10^{3}\right)$ the bacteria did not multiply and began to die after about $50 \mathrm{hr}$. (Fig. 1). It is not known whether increase of cell substance was inhibited or only the actual division of the bacteria, because only the number of viable bacteria was measured at this stage. The inhibition was overcome by adding 1/1000 whole blood or lysed red blood cells; higher dilutions of these materials gave growth more slowly. Fisher (1948) showed that crude serum albumin allowed growth of $B$. pertussis from small inocula in autoclaved media, and serum or electrophoretically pure serum albumin replaced red blood cells in my experiments. However, growth with serum $(1 / 400)$ was slower than that with the concentration of lysed red blood cells $(1 / 1000)$ containing the equivalent concentration of protein per unit volume. The course of the growth curve with serum was not found but it is possible that albumin was as efficient as red blood cells in overcoming colloidal sulphide and sulphur inhibition but unable to maintain the primary growth rate (see p. 287).

Cysteine sterilized by filtration overcomes inhibition by colloidal sulphur (Woiwod, 1954). Colloidal sulphur may be present in casein hydrolysates but the amount in Casamino Acids was small because omission of cysteine from CW 1 leaving the yeast extract as the sole source of sulphydryl groups did not slow growth significantly. However, Jebb \& Tomlinson (1955) grew Bordetella pertussis from small inocula in media autoclaved with cystine in which the Casamino Acids had been treated with activated charcoal. Using autoclaved cysteine instead of cystine, I obtained growth when the Casamino Acids had 
been treated with one batch of activated charcoal (British Drug Houses Ltd.) but not with another batch of the same make or with a batch of Norite. Autoclaved cystine was as inhibitory as autoclaved cysteine. Consequently it seems probable either that a compound increasing the formation of inhibitor from cysteine or cystine was removed by the charcoal, or that one overcoming the inhibition was added.

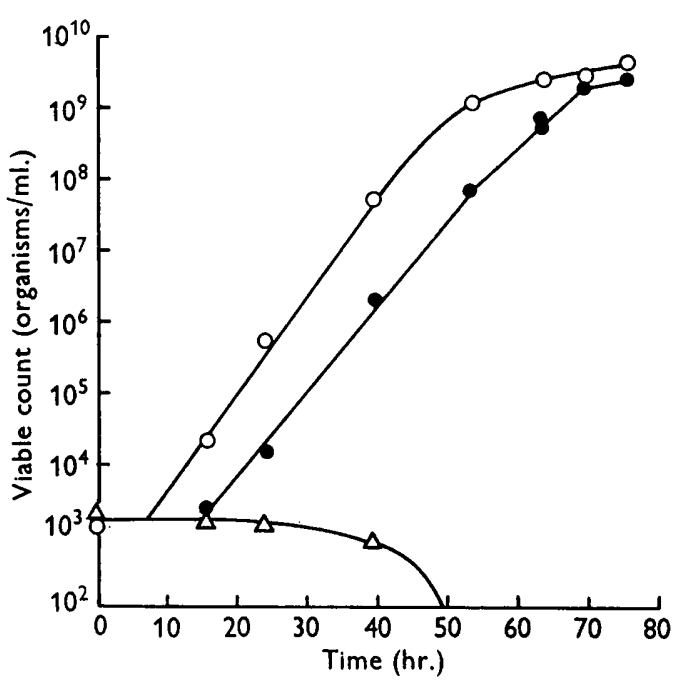

Fig. 1

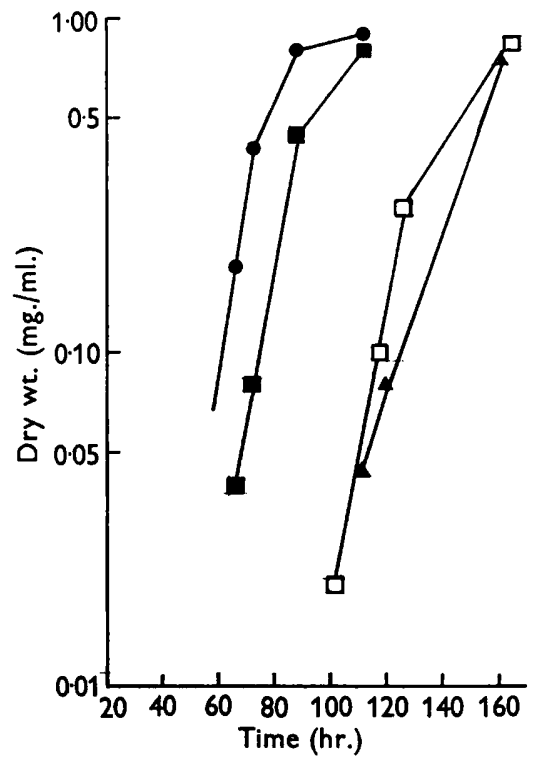

Fig. 2

Fig. 1. Inhibition of growth of Bordetella pertussis by autoclaved cysteine. Cultures incubated at $35^{\circ}$ in $20 \mathrm{ml}$. medium. The medium contained $1 \%(\mathrm{w} / \mathrm{v})$ Casamino Acids with cysteine autoclaved in the medium (CW a) or sterilized by Seitz-filtration (CW 1) or CW $1+1 / 100$ lysed R.в.c. Strain 467. CWa, $\triangle-\triangle$; CW 1, -O; CW 1 + blood, $\mathrm{O}-\mathrm{O}$.

Fig. 2. Effect of concentration of Casamino Acids on growth of Bordetella pertussis. Cultures incubated at $35^{\circ}$ in $20 \mathrm{ml}$. medium CW2 containing $0 \cdot 14 \%(w / v)$ glutamic acid and stated concentration of vitamin-free Casamino Acids (B. pertussis strain 467) or Casamino Acids (iron-free) (B. pertussis strain 593). Inocula $c .10^{3}$ bacteria $/ \mathrm{ml}$. Casamino Acids vitamin-free: $1 \%, 0 ; 0.7 \%, \square-\mathbf{0} ; 0.5 \%, \Delta-\Delta$; Casamino Acids iron-free : $0.7 \%, \mathrm{O}-\mathrm{O}$.

Effects of albumin. Pollock (1947) found that a degraded strain of Bordetella pertussis, 'Pertussis A', would not grow in broth unless albumin was added, and oleic acid $(4 \mu \mathrm{g} . / \mathrm{ml}$.) prevented the growth so obtained. At this concentration of oleic acid, growth of phase I B. pertussis in CW 1 was not affected. At 5 times the concentration $(25 \mu \mathrm{g} . / \mathrm{ml}$.) visible growth was prevented, but 1/1000 lysed red blood cells did not affect the inhibition. The inhibition by oleic acid, therefore, although it was also overcome by albumin seemed due to a different effect from that by autoclaved cysteine.

Effect of low concentrations of Casamino Acids. In the experiments quoted above, the medium contained $1 \%$ (w/v) Difco Bacto-vitamin-free Casamino Acids. When the concentration of Casamino Acids was decreased and glutamic 
acid added instead (see below), the period before a visible turbidity appeared became longer: in $1 \%(\mathrm{w} / \mathrm{v})$ Casamino Acids a given turbidity was reached $10 \mathrm{hr}$. earlier than in $0.7 \%(\mathrm{w} / \mathrm{v})$ Casamino Acids and $60 \mathrm{hr}$. earlier than in $0.5 \%$ (w/v) Casamino Acids (Fig. 2); 0.3\% (w/v) Casamino Acids in this medium (CW2) did not give visible turbidity. Viable counts showed that with the lower concentrations of Casamino Acids the lag period was longer although the growth rate was unaffected. For example, in an experiment with $1 \%$ (w/v) Casamino Acids the M.G.T. was 2.7 and the lag period about $10 \mathrm{hr}$; with $0.4 \%$ the M.G.T. was 2.5 and the lag period $40 \mathrm{hr}$. Bacteria incubated in media containing $0 \cdot 1 \%(\mathrm{w} / \mathrm{v})$ Casamino Acids (CW3) died rapidly (Fig. 3); the colony count had fallen considerably after $18 \mathrm{hr}$. In some experiments in which the organisms grew after a long lag period it seemed that only a small proportion of the original inoculum grew. The colony count fell abruptly and all bacteria seemed to be dead; as soon as sufficient bacteria were present to be measured, they were growing at the normal logarithmic rate. This was quite different from the effect with autoclaved cysteine when the viable count remained the same for nearly $40 \mathrm{hr}$. (Fig. 1).

Effect of red blood cells. The addition of whole blood allowed growth in $0.1 \%(\mathrm{w} / \mathrm{v})$ Casamino Acids (CW3) giving a lag period of the same length as or shorter than that in $1 \%(\mathrm{w} / \mathrm{v})$ Casamino Acids (Fig. 3). This time the activity was in the red cells. In the experiment shown in Table 1, growth with 1/4000 plasma was much slower than that with $1 / 10,000$ lysed red blood cells and 1/40,000 plasma did not give growth at all, although $1 / 100,000$ red blood cells gave growth as rapidly as $1 / 10,000$ red blood cells. As the red blood cells contain $\mathbf{2 . 5}$ times as much protein per unit volume as plasma does, the effect cannot be due to protein as such.

\section{Table 1. Growth of Bordetella pertussis in $0 \cdot 1 \%$ Casamino Acids with R.B.c. and plasma}

Cultures incubated at $35^{\circ}$ in $20 \mathrm{ml}$. CW3 medium $(0 \cdot 1 \% \mathrm{w} / \mathrm{v}$ Casamino Acids) with stated concentrations of R.B.c. and plasma. Strain M 2400, inoculum approx. $10^{3}$ bacteria $/ \mathrm{ml}$.

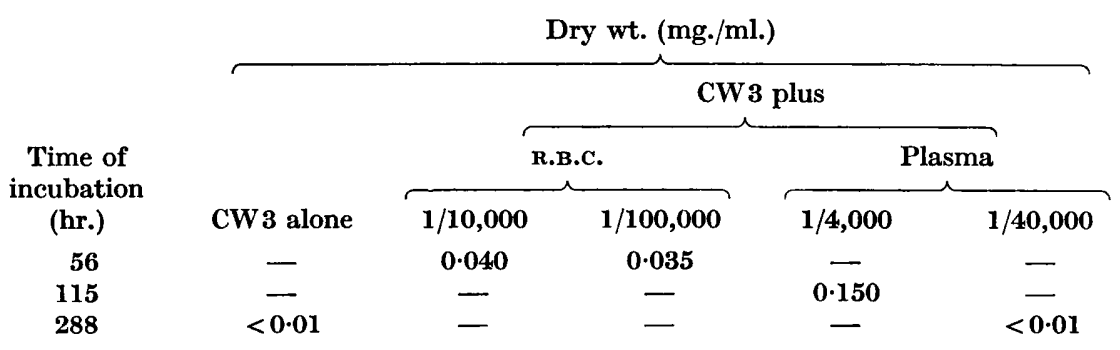

The quantity of red blood cells required varied with different batches of media. In some experiments, $1 / 500,000$ red blood cells gave as rapid growth as $1 / 10,000$ and in others $1 / 50,000$ gave slightly slower growth than $1 / 10,000$ red blood cells. The same variation was found with CW2 containing $0 \cdot 4 \%(\mathrm{w} / \mathrm{v})$ Casamino Acids which on one occasion had a lag period of only $24 \mathrm{hr}$. compared with $40 \mathrm{hr}$. in the experiment quoted above. 
Effect of haemin. The high activity of blood in promoting growth in CW3 suggested that haemin might be responsible. When this compound was added to the medium before autoclaving the organisms grew, but they generally grew more slowly than with lysed red blood cells with a lengthened lag period; with $2.5 \mu \mathrm{g}$. haemin $/ \mathrm{ml}$., the lag period was usually about $25 \mathrm{hr}$. although in one experiment it was $65 \mathrm{hr}$. The M.G.T. was still the same as with $1 / 10,000$ red blood cells (Fig. 3).

Haemin which had been sterilized by filtration through a Gradocol membrane gave a visible turbidity more rapidly than the same quantity of haemin sterilized by autoclaving (Table 2 ). In most experiments, $\mathbf{0} \cdot \mathbf{2 5} \mu \mathrm{g}$. haemin $/ \mathrm{ml}$. was not enough to promote growth, but in one experiment growth with this concentration of filtered haemin and also with autoclaved haemin $(2.5 \mu \mathrm{g} . / \mathrm{ml}$.) was as rapid as with 1/10,000 lysed red blood cells. This suggests that the variation is related to the medium rather than the haemin. Recrystallized haemin gave as variable growth as the commercial samples.

\section{Table 2. Growth of Bordetella pertussis in $0 \cdot 1 \%$ Casamino Acids with haemin and iron salts}

Cultures incubated at $35^{\circ}$ in $20 \mathrm{ml}$. CW3 $(0 \cdot 1 \% \mathrm{w} / \mathrm{v}$ Casamino Acids $) . \mathrm{FeSO}_{4} \cdot 7 \mathrm{H}_{2} \mathrm{O}$ $(12.5 \mu \mathrm{g} . / \mathrm{ml}$.) was autoclaved in the medium when Seitz-filtered or autoclaved haemin was added but not when Seitz-filtered $\mathrm{FeSO}_{4}$ was added to the autoclaved medium. $\mathrm{FeSO}_{4}$ was sterilized by Seitz-filtration in acid solution; haemin was sterilized by filtration through a Gradocol membrane in alkaline solution. Strain 467 inoculum c. $10^{3}$ bacteria $/ \mathrm{ml}$.

\begin{tabular}{|c|c|c|c|c|c|c|c|c|}
\hline \multirow[b]{2}{*}{ Compound } & \multirow{2}{*}{$\begin{array}{c}\text { Concen- } \\
\text { tration } \\
(\mu \mathrm{g} . / \mathrm{ml} .)\end{array}$} & \multirow{2}{*}{$\begin{array}{l}\text { Method of } \\
\text { sterilization }\end{array}$} & \multicolumn{6}{|c|}{$\begin{array}{l}\text { Dry wt. (mg./ml.). } \\
\text { Incubation time (hr.) }\end{array}$} \\
\hline & & & $63 \frac{1}{2}$ & 72 & $89 \frac{1}{2}$ & 112 & 120 & 240 \\
\hline \multirow[t]{2}{*}{$\mathrm{FeSO}_{4} \cdot 7 \mathrm{H}_{2} \mathrm{O}$} & $\begin{array}{l}12.5 \\
13.5\end{array}$ & $\begin{array}{l}\text { Autoclaving } \\
\text { Filtration }\end{array}$ & $0 . \overline{025}$ & - & - & $\overline{0.50}$ & - & $<0.01$ \\
\hline & $1 \cdot 33$ & Filtration & - & - & - & - & - & $<0.01$ \\
\hline \multirow[t]{3}{*}{ Haemin } & $2 \cdot 5$ & Autoclaving & - & - & $0 \cdot 045$ & - & - & - \\
\hline & $2 \cdot 5$ & Filtration & - & 0.035 & - & - & 0.475 & - \\
\hline & $0 \cdot 25$ & Filtration & - & - & - & - & - & $<0.01$ \\
\hline
\end{tabular}

Effect of iron. Small inocula grew in the medium containing $0 \cdot 1 \%(\mathrm{w} / \mathrm{v})$ Casamino Acids (CW 3) when ferrous sulphate sterilized by filtration was added to the medium after autoclaving (CW 4). The lag period with $12 \cdot 5 \mu \mathrm{g}$. $\mathrm{FeSO}_{4} \cdot 7 \mathrm{H}_{2} \mathrm{O} / \mathrm{ml}$. was approximately the same as that with $1 / 10,000$ red blood cells (Fig. 3); with lower concentrations of $\mathrm{FeSO}_{4}$, the lag period was longer, and concentrations below $1 \mu \mathrm{g} . / \mathrm{ml}$. usually did not give growth.

The medium already contained $\mathrm{FeSO}_{4}$ autoclaved with the other ingredients, but increasing the concentration of autoclaved $\mathrm{FeSO}_{4}$ did not allow growth in $\mathrm{CW} 3$, and the autoclaved $\mathrm{FeSO}_{4}$ could be left out without increasing the concentration of filtered $\mathrm{FeSO}_{4}$. When it was sterilized by filtration, ferrous ammonium sulphate, which contains less impurity than $\mathrm{FeSO}_{4}$ (analytical reagent grade), stimulated growth as well as $\mathrm{FeSO}_{\mathbf{4}}$.

Action of supplements. It was thus possible to obtain growth in a medium with $0 \cdot 1 \%(\mathrm{w} / \mathrm{v})$ Casamino Acids by the addition of red blood cells, filtered 
ferrous sulphate, haemin, or by increasing the Casamino Acids concentration to $1 \%(\mathrm{w} / \mathrm{v})$. It was unlikely that haemin was the true growth factor because it was the least effective of the substances and Casamino Acids in $1 \%(\mathrm{w} / \mathrm{v})$ solution contained less than $\mathbf{0 . 0 1} \mu \mathrm{g}$. haemin $/ \mathrm{ml}$. (Professor C. Rimington, private communication). The lowest concentration of $\mathrm{FeSO}_{4}$ which allowed growth contained $\mathbf{0 . 2} \mu \mathrm{g}$. Fe $/ \mathrm{ml}$. Vitamin-free Casamino Acids in $1 \%(\mathrm{w} / \mathrm{v})$ solution contained only $0.08 \mu \mathrm{g}$. Fe/ml. Bacto-Casamino Acids (iron-free) for the growth of Corynebacterium diphtheriae contained $0 \cdot 0002 \mu \mathrm{g}$. Fe/ml. $1 \%$ (w/v) solution, but gave only slightly slower growth of Bordetella pertussis than the vitamin-free hydrolysate: a $0.7 \%(\mathrm{w} / \mathrm{v})$ solution of the iron-free hydrolysate gave a visible turbidity at the same time as a $0.5 \%(w / v)$ solution of the vitamin-free hydrolysate. If the stimulation by these two hydrolysates had been due to iron salts, the effect of the iron-free hydrolysate would have been relatively much less.

Ferrous sulphate and haemin are both reducing agents, and it was thought that the redox potential of the medium might be important. An attempt was made to measure it with phenolindo-2:6-dichlorophenol which has an $E_{0}^{\prime}$ at $\mathrm{pH} \mathrm{7.0}$ of $+0 \cdot 217 \mathrm{~V}$. Cysteine which did not promote growth with $0.1 \%$ (w/v) Casamino Acids reduced the dye instantaneously. Ferrous sulphate which did promote growth reduced the dye slowly. Vitamin-free Casamino Acids reduced it slightly more quickly and Casamino Acids (iron-free) had very little effect on it. The result with cysteine suggests that the redox potential is not the factor governing growth.

Peroxides have been suggested as inhibitors of the growth of some organisms from small inocula (Gilder \& Granick, 1948; Herbert, 1949), and ferrous ammonium sulphate and haemin permitted growth of Haemophilus parainfluenzae in such circumstances (Gilder \& Granick, 1948). Ferrous sulphate, haemin and blood all destroy hydrogen peroxide, but permanganate titration showed that cysteine which did not support growth destroyed hydrogen peroxide rapidly. The destruction of hydrogen peroxide by Casamino Acids was not tested.

The active substance in Casamino Acids (vitamin-free) was partially removed by monochloroacetic acid + ether and the longer it remained with the monochloroacetate before the ether extraction the less activity was left. Passing through a column of Amberlite IRA 400 treated with monochloroacetate (see Schramm, Moore \& Bigwood, 1954) and extracting with ether removed it completely but it is possible that this was merely the result of prolonged treatment with monochloroacetate.

\section{Effect of various factors on growth rate}

None of the factors mentioned in the preceding section had very much effect on the mean generation time (M.G.T.) which was usually $2 \cdot 3-2 \cdot 8 \mathrm{hr}$. Addition of lysed red blood cells to media with $1 \%$ or $0.1 \%(w / v)$ Casamino Acids usually decreased the M.G.T. slightly but only by about $0.5 \mathrm{hr}$. (Figs. 1, 3). This effect might be greater with an inoculum from a blood-free medium such as charcoal Cohen agar (see Mazloum \& Rowley, 1955). When nicotin- 
amide replaced yeast extract in medium CW 4 turbidity appeared later and with Casamino Acids left out as well growth was still slower (Table 3), but it is not known which phase of growth was affected. In my hands Proom's (1955) medium which contains 8 amino acids, starch, nicotinamide and salts gave very little multiplication and even with yeast extract added the M.G.T. was slower than that with medium CW 1. The medium of Jebb \& Tomlinson (1955) containing charcoal-treated Casamino Acids, nicotinamide, purines, biotin and haemin gave very irregular slow growth. These two are the only simple media in which growth rates have been measured.

\section{Table 3. Effect of nicotinamide on growth of Bordetella pertussis}

Cultures grown at $35^{\circ}$ in CW2 with Casamino Acids, iron and yeast extract as below. Haemin was sterilized by autoclaving in the medium, $\mathrm{FeSO}_{4}$ was sterilized by Seitz-filtration and was not added before autoclaving. The flasks with haemin contained iron only as impurity. Nicotinamide (5 $\mu \mathrm{g} . / \mathrm{ml}$.) was autoclaved in the medium. Strain 467 , inoculum $c$. $10^{3}$ bacteria/ml.

\begin{tabular}{|c|c|c|c|c|c|c|c|}
\hline \multicolumn{3}{|c|}{ Additions } & \multicolumn{5}{|c|}{$\begin{array}{l}\text { Dry wt. (mg./ml.). } \\
\text { Incubation time (hr.) }\end{array}$} \\
\hline $\begin{array}{c}\text { Casamino } \\
\text { Acids }\end{array}$ & $\begin{array}{c}\text { Growth } \\
\text { factor }\end{array}$ & Iron source & 63 & $139 \frac{1}{2}$ & 166 & 183 & $231 \frac{1}{2}$ \\
\hline $0.1 \%$ & Yeast extract & $\mathrm{FeSO}_{4} \cdot 7 \mathrm{H}_{2} \mathrm{O}(12.5 \mu \mathrm{g} . / \mathrm{ml})$. & $0 \cdot 04$ & 0.50 & - & - & - \\
\hline $0.1 \%$ & Nicotinamide & $\mathrm{FeSO}_{4} \cdot 7 \mathrm{H}_{2} \mathrm{O}(12.5 \mu \mathrm{g} . / \mathrm{ml})$. & - & $\mathbf{0} \cdot 35$ & - & 0.55 & 一 \\
\hline $0 \cdot 1 \%$ & Nicotinamide & Haemin (2.5 $\mu \mathrm{g} . / \mathrm{ml})$. & - & $\mathbf{0} \cdot \mathbf{2 0}$ & 一 & $0 \cdot 475$ & - \\
\hline $\mathbf{0}$ & Nicotinamide & $\mathrm{FeSO}_{4} \cdot 7 \mathrm{H}_{2} \mathrm{O}(12.5 \mu \mathrm{g} . / \mathrm{ml})$. & - & - & $0 \cdot 03$ & - & $0 \cdot 375$ \\
\hline o & Nicotinamide & Haemin $(2.5 \mu \mathrm{g} . / \mathrm{ml})$. & - & - & - & 0.325 & 0.475 \\
\hline
\end{tabular}

Secondary growth rate. Although the initial growth rate in CW media was always about the same, the time taken to reach a given turbidity was varied by the presence of a secondary slower logarithmic growth rate. This occurred in all experiments tested with $0.1 \%(\mathrm{w} / \mathrm{v})$ Casamino Acids $+\mathrm{FeSO}_{4}$ medium (CW 4) and in almost all with $0 \cdot 1 \%(\mathrm{w} / \mathrm{v})$ Casamino Acids + lysed red blood cells. In the experiment shown in Fig. 3, the M.G.T. fell slightly earlier in the medium $+\mathrm{FeSO}_{4}$ than in that with lysed red blood cells so that after $63 \mathrm{hr}$. the dry weight with red blood cells was 4 times that with $\mathrm{FeSO}_{4}$. With media containing $1 \%$ (w/v) Casamino Acids (CW1 or CW 2), the secondary growth rate was present in about $1 / 3$ of the experiments; in the rest, either the primary growth rate was maintained to the end or data were insufficient to give the exact course of the curve. With this medium, there was some correlation between size of inoculum and presence of secondary growth rate: in ten experiments with a single logarithmic growth rate the inoculum was between $5 \times 10^{2}$ and $4 \times 10^{3}$; in six experiments with 2 logarithmic growth rates, four had an inoculum between $1 \times 10^{2}$ and $5 \times 10^{2}$ and two an inoculum of $1 \times 10^{3}$ bacteria/ml.

The secondary M.G.T. in medium CW 1 was generally between $3 \cdot 1$ and $3.8 \mathrm{hr}$.; in medium CW3 with red blood cells or $\mathrm{FeSO}_{4}$ it was between 4 and $7 \mathrm{hr}$. The change occurred at a viable count of between $10^{6}$ and $10^{8}$ and could not be explained by change in $\mathrm{pH}$ value, lack of glutamate, excess of ammonia (Table 4 and Fig. 1) or lack of oxygen. The aeration rate was not limiting until $0 \cdot 1 \mathrm{mg}$. dry weight bacteria/ml. was present (see below). 
The addition of 1/100 lysed red blood cells to medium CW 1 kept growth at the primary rate throughout (Fig. 1). A secondary growth rate was present with 1/10,000 red blood cells and $0 \cdot 1 \%$ (w/v) Casamino Acids (Fig. 3), and the appearance of turbidity was slower in this medium than with $1 / 1000$ red blood cells with $1 \%(\mathrm{w} / \mathrm{v})$ Casamino Acids (Table 6), suggesting that the primary growth rate went on for longer with 1/1000 red blood cells. The optimal concentration of red blood cells is not known.

Table 4. Medium composition at start of secondary M.G.T.

Data as in Fig. 1 for filtered cysteine (CW 1).

\begin{tabular}{|c|c|c|c|c|c|c|}
\hline \multirow{2}{*}{$\begin{array}{c}\text { Time of } \\
\text { incubation } \\
\text { (hr.) }\end{array}$} & \multirow{2}{*}{$\begin{array}{c}\text { Dry wt. of } \\
\text { bacteria } \\
\text { (mg./ml.) }\end{array}$} & \multirow[b]{2}{*}{$\mathrm{pH}$} & \multicolumn{2}{|c|}{$\begin{array}{c}\text { Glutamate } \\
(\mu \mathrm{l} . / \mathrm{ml} .)\end{array}$} & \multicolumn{2}{|c|}{$\underset{(\mu \mathrm{l} . / \mathrm{ml} .)}{\text { Ammonia }}$} \\
\hline & & & Total & Used & Total & Formed \\
\hline 0 & - & 6.90 & 106 & - & 129 & - \\
\hline $53 \frac{1}{4}$ & 0.02 & 6.89 & - & - & 124 & -5 \\
\hline $63 \frac{1}{2}$ & 0.085 & $7 \cdot 20$ & 95 & 11 & 134 & 5 \\
\hline
\end{tabular}

$p H$. The only difference in growth noted between $\mathrm{pH} 6 \cdot 9$ and $7 \cdot 7$ was that the secondary growth rate at $\mathrm{pH} 7 \cdot 5-7 \cdot 7$ was slightly slower than at the lower $\mathrm{pH}$, for example 4.2 instead of $3.7 \mathrm{hr}$. In one experiment after $65 \mathrm{hr}$. incubation the dry weight of bacteria at $\mathrm{pH} 7.7$ was only $0.01 \mathrm{mg}$. $/ \mathrm{ml}$. while that at the lower $\mathrm{pH}$ values was $0.10 \mathrm{mg}$. $/ \mathrm{ml}$. Unfortunately the media used in these experiments did not contain extra glutamate and the total crop of bacteria at each $\mathrm{pH}$ was only $0.5-0.6 \mathrm{mg}$. $/ \mathrm{ml}$. which may have been too small to show an effect of $\mathrm{pH}$ on the total yield of organisms.

Effect of aeration. Experiments on aeration were carried out in large-scale cultures with large crops of bacteria. The medium used contained $1 \%(\mathrm{w} / \mathrm{v})$ casein hydrolysate and $0 \cdot 1 \%(\mathrm{w} / \mathrm{v})$ glutamate (LS 1$)$. Different volumes of culture medium in penicillin flasks were shaken on a shaker with shelves moving at three different rates (Kantorowicz, 1951). In the largest volume of culture $(500 \mathrm{ml}$.) shaken at the slowest rate growth was the same as in the other flasks until a dry weight of $0.15 \mathrm{mg} . / \mathrm{ml}$. was reached and then the growth rate became progressively slower (Fig. 4) as each increase in dry weight made more oxygen necessary.

Growth rate and turbidity. The growth rate as measured by viable count and by turbidity was approximately the same until the maximum turbidity was reached (Fig. 5). The growth rate as measured by turbidity was never as rapid as the primary growth rate; by the time a visible turbidity was present, either the primary growth rate had started to fall (curve A), or the secondary growth rate was operating (curve B). Bordetella pertussis may be different from other organisms, but these findings suggest that the growth rate of bacteria in the visible range should not be taken as indicative of that at an earlier stage.

The total count was not measured and the turbidity of the American N.I.H. 'Haemophilus pertussis' vaccine standard of $10,000 \times 10^{6}$ organisms $/ \mathrm{ml}$. was approximately equivalent to $\mathbf{0} \cdot \mathbf{2} \mathrm{mg}$. bacteria $/ \mathrm{ml}$. of a $\mathbf{7 2} \mathrm{hr}$. large-scale culture. Assuming this to be correct the viable count was only $20 \%$ of the 
total, a much lower value than has been found by other workers (see Monod, 1949). Although these values may not be strictly accurate it is probable that the American standard is not thick enough for the number of bacteria it is said to represent.

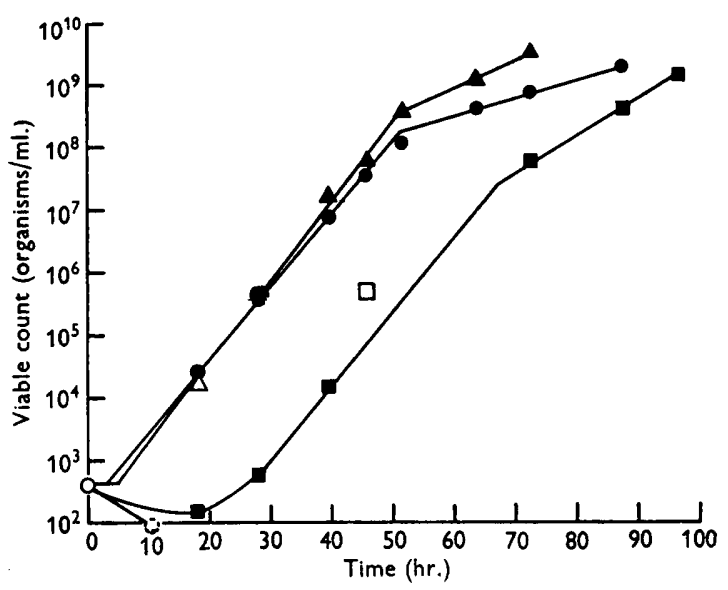

Fig. 3

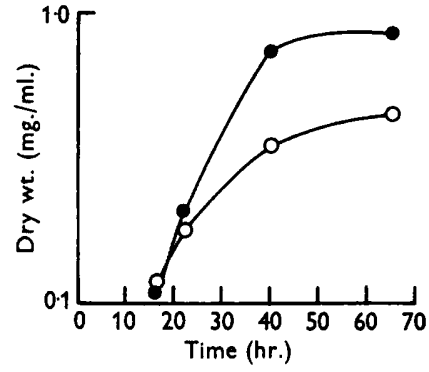

Fig. 4

Fig. 3. Stimulation of growth in $0 \cdot 1 \%$ (w/v) Casamino Acids by R.B.c., haemin and $\mathrm{FeSO}_{4}$. Cultures incubated at $35^{\circ} \mathrm{C}$. in $20 \mathrm{ml}$. medium CW3 with $0 \cdot 1 \%$ (w/v) Casamino Acids and additions as stated. Strain 467. CW3 without addition, $\mathrm{O}-\mathrm{O}$; with 1/10,000 lysed R.B.c., $\Delta-\Delta$; with haemin $(2 \mu \mathrm{g} . / \mathrm{ml}$.$) , autoclaved in the medium, \square-\square ;$ with $\mathrm{FeSO}_{4} .7 \mathrm{H}_{2} \mathrm{O}(12 \cdot 5 \mu \mathrm{g} . / \mathrm{ml}$.) sterilized by Seitz-filtration, $\longrightarrow$. The number of colonies in the samples marked by the open square and the open triangle was too great to count accurately, and that in the dotted circle was too small.

Fig. 4. Effect of aeration rate on rate of growth. Cultures incubated at $35^{\circ}$ in stated volumes of medium in penicillin flasks and shaken slowly. Medium LS1 containing $1 \%(\mathrm{w} / \mathrm{v})$ Benger's Casein hydrolysate. Strain 467 . Inoculum $c .10^{7} \mathrm{bacteria} / \mathrm{ml} .500 \mathrm{ml}$. medium/flask, $\mathrm{O}-\mathrm{O} ; 250 \mathrm{ml}$. medium/flask, $\bullet$.

\section{Factors affecting the yield of bacteria}

Glutamic acid. It was shown earlier (Rowatt, 1955) that the main amino acid used in growth of Bordetella pertussis was glutamic acid. The addition of more glutamic acid to a medium containing $1 \%$ (w/v) Casamino Acids (CW 2) increased the crop of bacteria, the maximum being $1 \mathrm{mg}$. bacteria $/ \mathrm{ml}$. with a total concentration of $0.2 \%(\mathrm{w} / \mathrm{v})$ glutamic acid $(0.07 \%$ in $1 \%(\mathrm{w} / \mathrm{v})$ Casamino Acids and $\mathbf{0} \cdot 13 \%(\mathrm{w} / \mathrm{v})$ glutamic acid added). In this medium, the utilization of other amino acids was suppressed, only glutamate and alanine being used to a sufficient extent to show on paper chromatograms. At concentrations of glutamic acid above $\mathbf{0 . 2} \%(\mathrm{w} / \mathrm{v})$ growth stopped before all the glutamate had been used, showing that another factor was limiting.

In experiments with $500 \mathrm{ml}$. medium/flask and an inoculum of $10^{7}$ organisms/ $\mathrm{ml}$, crops of $2.0-2.5 \mathrm{mg} . / \mathrm{ml}$. could be obtained. The crop of bacteria was proportional to the concentration of glutamate up to $0.3 \%(w / v)$ giving approximately $1 \mathrm{mg}$. bacteria $/ 2 \mathrm{mg}$. glutamate (Fig. 6). The mean generation time as measured by turbidity was approximately $5 \mathrm{hr}$. with concentrations of 
glutamate up to $0.5 \%(\mathrm{w} / \mathrm{v})$, but with $1 \%(\mathrm{w} / \mathrm{v})$ glutamate it was reduced to $8 \mathrm{hr}$. or more. The medium used for these experiments (LS2) contained, instead of Casamino Acids, a pancreatic digest of casein (Benger Laboratories Ltd., Holmes Chapel) in which the concentration of free amino acids in a $1 \%$ $(\mathrm{w} / \mathrm{v})$ solution was approximately the same as that in $0.1 \%(\mathrm{w} / \mathrm{v})$ Casamino Acids. The difference in yield of organisms was not caused by the alteration in amino acid source because similar crops were obtained from Casamino Acids when large inocula were used, although the rate of growth was sometimes slower.

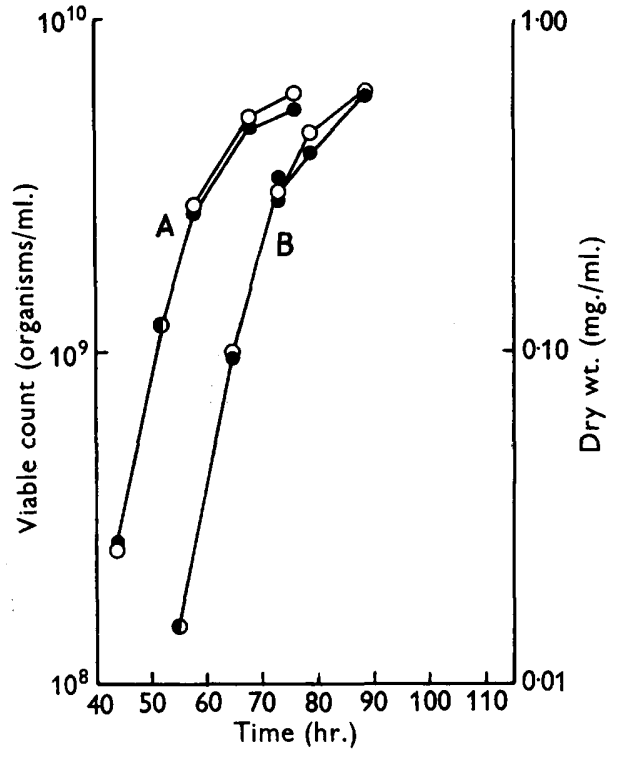

Fig. 5

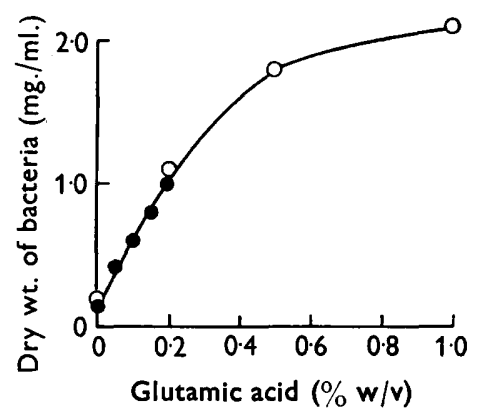

Fig. 6

Fig. 5. Comparison of growth rate as measured by viable count and by turbidity. Both cultures incubated at $35^{\circ}$ in $20 \mathrm{ml}$. medium CW 1 . A: strain 5339; inoculum $4 \times 10^{3}$ bacteria/ml.; primary M.G.T. ended at $44 \mathrm{hr}$. B: strain 951 ; inoculum $1.5 \times 10^{2}$ bacteria/ml.; primary M.G.T. ended at $41 \mathrm{hr}$., secondary M.G.T. ended at $65 \mathrm{hr}$. Viable count, $\longrightarrow$; dry wt., $\bigcirc-0$.

Fig. 6. Effect of glutamic acid on growth in large-scale experiments. Cultures incubated at $35^{\circ} \mathrm{C}$. in $500 \mathrm{ml}$. medium LS2 containing $1 \%(\mathrm{w} / \mathrm{v})$ Benger's casein hydrolysate and stated concentration of glutamic acid. Final crop plotted for each concentration after 40-72 hr. incubation. Inocula $c .10^{7}$ bacteria/ml. Strain M 2400, $-\bullet$; Strain 467, $\mathrm{O}-\mathrm{O}$.

During the growth of Bordetella pertussis glutamate was utilized with the formation of ammonia and a consequent increase in $\mathrm{pH}$; in medium $\mathrm{CW} 1$ approximately $1 \mathrm{ml}$. of $0.01 \mathrm{~N}$-alkali was formed during the growth of $1 \mathrm{mg}$. bacteria. In the large-scale medium (LS2) growth was never obtained at a higher $\mathrm{pH}$ than $\mathbf{8 \cdot 2 - 8 . 3}$ even with $1 \%(\mathrm{w} / \mathrm{v})$ glutamate, and this $\mathrm{pH}$ is probably the limiting value. After growth had stopped the $\mathrm{pH}$ of the medium rose further, sometimes to $\mathrm{pH} 9 \cdot \mathbf{0}$, either by oxidation of glutamate or its breakdown products or by deamination of other amino acids. 
Reducing the concentration of Casamino Acids in small-scale media decreased the yield of bacteria slightly (from $\mathbf{1} \cdot 0 \mathrm{mg} . / \mathrm{ml}$. to $\mathbf{0} \cdot \mathbf{7}-\mathbf{0} \cdot \mathbf{8} \mathrm{mg} . / \mathrm{ml}$.) even though extra glutamate was added. In media containing $0 \cdot 1 \%(\mathrm{w} / \mathrm{v})$ Casamino Acids + haemin or $+\mathrm{FeSO}_{4}$ (CW 4) the bacteria formed a scum on the medium which crept up the sides of the vessel. This did not happen in the medium with $0 \cdot 1 \%(\mathrm{w} / \mathrm{v})$ Casamino Acids + lysed red blood cells or with $1 \%$ (w/v) Casamino Acids, and it is probable that the medium $+\mathrm{FeSO}_{4}$, although it supports growth, does not produce normal bacteria.

Cysteine or cystine is necessary for growth (Hornibrook, 1939). In largescale experiments leaving out the casein hydrolysate (LS3) reduced the yield of bacteria to approximately $0.8 \mathrm{mg} . / \mathrm{ml}$. or $1 / 3$ of that with casein hydrolysate (LS 2). Preliminary experiments suggested that the crop could be doubled by using filtered instead of autoclaved cysteine $(0.03 \mathrm{mg} . / \mathrm{ml}$.) (LS 4), but growth was not increased further with more cysteine. This quantity of growth was obtained with $0.06 \mathrm{mg}$. autoclaved cysteine/ml. (LS3) and higher concentrations of autoclaved cysteine were inhibitory. It is possible that in the presence of casein hydrolysate the cysteine is more stable and less of the inhibitory breakdown products is formed.

Apart from glutamic acid and cysteine only alanine was used in any quantity during the early stages of growth. This could be seen from chromatograms of cultures in large-scale experiments in $0.5 \%(\mathrm{w} / \mathrm{v})$ glutamate without any casein hydrolysate (LS3). Alanine was not an essential amino acid because the alanine spot on the chromatogram frequently became darker during growth indicating a synthesis of alanine. Further, its addition in the DL-form to medium LS3 did not increase growth.

Not all of the nitrogen of the glutamate used appeared as ammonia. The missing nitrogen was not sufficient to account for the bacterial nitrogen and some must have come from other amino acids, but since the bacterial nitrogen and the non-glutamate nitrogen were of the same order and some amino acids remained after growth, a substantial part of the bacterial nitrogen must have come from glutamate (Table 5). The bacterial nitrogen was found to be $10 \%$ of the dry weight, rather than the $12 \%$ quoted previously (Rowatt, 1955).

\section{Table 5. Source of bacterial nitrogen}

Culture incubated at $35^{\circ} 40 \mathrm{hr}$. in $500 \mathrm{ml}$. LS3 $0.5 \%(\mathrm{w} / \mathrm{v})$ glutamic acid without casein hydrolysate. Bacterial $\mathrm{N}$ taken as $10 \%$ of dry wt. Strain 467 . Inoculum $2 \times 10^{7}$ bacteria $/ \mathrm{ml}$.

\begin{tabular}{|c|c|c|c|c|}
\hline $\begin{array}{l}\text { Dry wt. } \\
\text { (mg./ml.) }\end{array}$ & $\begin{array}{c}\text { Bacterial } \\
\mathbf{N} \\
(\mu \mathrm{mole} / \mathrm{ml} .)\end{array}$ & $\begin{array}{c}\text { Glutamate } \\
\text { used } \\
(\mu \mathrm{mole} / \mathrm{ml} .)\end{array}$ & $\begin{array}{c}\text { Glutamate } \\
\text { used minus } \\
\mathrm{NH}_{3} \text { formed } \\
(\mu \mathrm{mole} / \mathrm{ml} .)\end{array}$ & $\begin{array}{c}\text { Initial amino } \\
\mathrm{N} \text { other than } \\
\text { glutamate and } \\
\mathrm{NH}_{\mathbf{3}} \\
(\mu \mathrm{mole} / \mathrm{ml} .)\end{array}$ \\
\hline $0 \cdot 70$ & 5 & $12 \cdot 8$ & $4 \cdot 9$ & $4 \cdot 7$ \\
\hline
\end{tabular}

Growth factors. The replacement of yeast extract by nicotinamide in medium CW 4 with $0 \cdot 1 \%(w / v)$ Casamino Acids $+\mathrm{FeSO}_{4}$, although it made growth become visible later, did not alter the crop of bacteria significantly 
(Table 3). The yield with yeast extract and 1/10,000 lysed red blood cells was no better but when a large inoculum was used in the medium with $0.1 \%(\mathrm{w} / \mathrm{v})$ Casamino Acids without red blood cells on a large scale, the yield of bacteria was of the order of $1.5 \mathrm{mg}$. dry weight $/ \mathrm{ml}$.

\section{Autoclaved cysteine and $0 \cdot 1 \%(w / v)$ Casamino Acids in growth of other Bordetella}

Autoclaved cysteine slowed the growth of Pollock's (1947) 'Pertussis A' and this strain would not grow in $0 \cdot 1 \%(\mathrm{w} / \mathrm{v})$ Casamino Acids unless blood was added (Table 6). Phase IV CN2217 and NCTC 364, which grow on digest agar, grew slowly with autoclaved cysteine but not with $0 \cdot 1 \%(\mathrm{w} / \mathrm{v})$ Casamino Acids. Autoclaved cysteine did not affect the growth of G $146 \mathrm{E}$ but with $0 \cdot 1 \%(\mathrm{w} / \mathrm{v})$ Casamino Acids growth was slower. G 146E and G154 E both grew poorly in CW 1. Bordetella bronchiseptica, NCTC 8762, grew at the same rate in all the media, and gave a smaller crop with $0 \cdot 1 \%$ than with $1 \%(\mathrm{w} / \mathrm{v})$ Casamino Acids. B. parapertussis grew at the same rate in the media without blood and seemed to be unaffected by autoclaved cysteine or by 'peroxides' but a visible turbidity appeared sooner when blood was added. Unfortunately, the effect of filtered $\mathrm{FeSO}_{4}$ was not tested with any of these organisms.

\section{DISCUSSION}

Experiments on the growth requirements of Bordetella pertussis have always been complicated by the interplay of inhibitors. Two of these have been identified, namely colloidal sulphur or sulphides (Proom, 1955) and unsaturated fatty acids (Pollock, 1947). With the first of these the viable count remains stationary showing that division of the bacteria is inhibited. The main source of colloidal sulphur is autoclaved cysteine or cystine and can be eliminated by sterilizing these compounds by Seitz filtration. A small quantity of inhibitor may be introduced by protein hydrolysates or yeast extract. These can be sterilized by filtration, or autoclaved at acid $\mathrm{pH}$ or in the presence of phosphate or citrate to chelate heavy metals which accelerate the formation of colloidal sulphur or sulphides (Dr D. Herbert, private communication). Unsaturated fatty acids can be excluded by capping containers instead of plugging with cotton wool and by using a protein hydrolysate such as Casamino Acids which is low in fatty acids as estimated by Corynebacterium diphtheriae (Rowatt, unpublished experiments).

The nature of the third inhibitor is not yet established, but its removal by lysed red blood cells, haemin and filtered ferrous sulphate suggests that it might be a peroxide. The quantity of inhibitor as estimated by the amount of substance necessary to initiate growth varied with the batch of medium. The variable factor could not be the inoculum because in general three strains of organism were used with each batch of medium and each strain behaved in the same way with any one batch. This leaves the autoclaving of the medium as the cause of the inhibition. Peroxides are formed when media are 


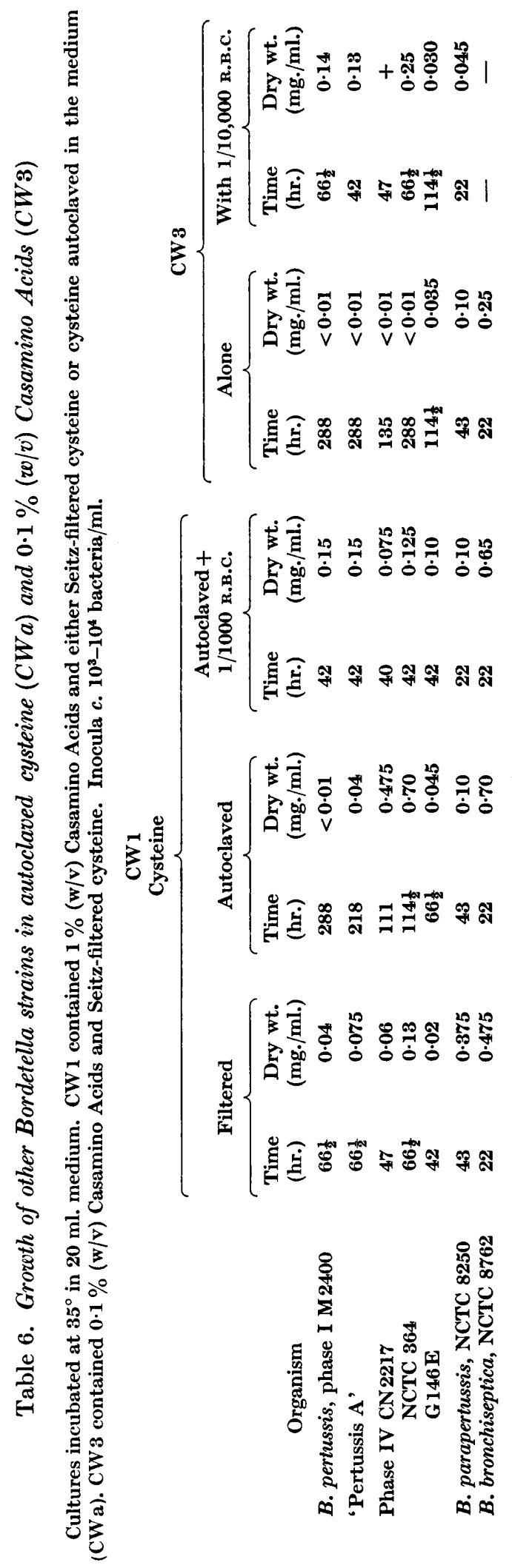

293 
autoclaved!at neutral $\mathrm{pH}$, and hydrogen peroxide has already been suggested as an inhibitor of Bordetella pertussis on solid media (Mazloum \& Rowley, 1955). However, since haemin destroys hydrogen peroxide more rapidly than $\mathrm{FeSO}_{4}$ does, but is less active in promoting growth, it is more probable that an organic peroxide is to blame. This question could be settled by the addition to the medium of catalase which destroys hydrogen peroxide but not other peroxides. Until the identity of this third inhibitor is established, it is not possible to know the easiest way of overcoming it. However, it should be borne in mind that organic peroxides formed from ethers or alcohols during heating might be responsible for inhibitory effects such as that mentioned on p. 286.

Bordetella pertussis grew rapidly only in the early stages of growth or in media containing high concentrations of lysed red blood cells. Since inocula were grown on a medium rich in blood (BG), the initial rapid growth rate may have been due to factors carried over in the inoculum. Small quantities of the substances concerned may have been present in Casamino Acids because the secondary growth rate was present always in media containing $0.1 \%$ but only sometimes in media containing $1 \%(\mathrm{w} / \mathrm{v})$ Casamino Acids. The variation with $1 \%(w / v)$ Casamino Acids shows that most of the factor is added with the inoculum which is the main variable. The slower secondary growth rate of B. parapertussis (Rowatt, 1955) is probably due to the same factor especially as growth of this organism became visible sooner when lysed red blood cells were added to the medium. B. parapertussis which was maintained on media without blood (DA) would be expected to show deficiency of a factor in blood more readily than $B$. pertussis which was maintained on media rich in blood (BG). Factors in yeast extract and Casamino Acids probably affected the growth rate of $B$. pertussis rather than the lag period, making the factors in the inoculum unable to maintain the rapid growth rate.

Glutamic acid and the buffering capacity of the medium are the major factors governing the yield of Bordetella pertussis in a medium. Cysteine and unidentified factors in Casamino Acids are also necessary, but one of the most important factors is one added to the culture medium with large inocula. This factor or group of factors doubles or trebles the yield of bacteria and must be at least partially identified before large crops of $\boldsymbol{B}$. pertussis can be obtained in simpler media than those described here.

Proom (1955) found that Bordetella parapertussis and $\boldsymbol{B}$. bronchiseptica are not inhibited by colloidal sulphur. I have shown that they are not inhibited by 'peroxide'. However, the phase IV strains except G146 E were all inhibited by the 'peroxide' medium and to some extent by autoclaved cysteine. G146E may have been slightly inhibited by autoclaved cysteine; in the 'peroxide' medium it grew very little, even with blood. It is not certain that the slowing of growth in $\mathbf{0} \cdot 1 \%$ (w/v) Casamino Acids (CW 3) was due to the same factor for each strain. The difference between these five derived strains is emphasized by these tests.

Bordetella pertussis requires blood to combat inhibitions by 'peroxide' and by autoclaved cysteine and to maintain the growth rate. The greater yield of 
bacteria when a large inoculum is used may be caused by some of the constituents of blood added with the inoculum. This organism has been grown in defined media but rapid and profuse growth cannot yet be obtained without blood, and for some time to come the most complete media will probably contain small concentrations of blood added either as such or in the inoculum.

This work was carried out while the author was seconded from the Central Public Health Laboratory, Colindale.

The author wishes to thank Dr D. Herbert for suggesting the form of the paper; Professor C. Rimington for kindly estimating the haemin content of Casamino Acids, for providing recrystallized haemin and for helpful discussions; Dr T. S. Work for information about organic peroxides; and Mr A. F. B. Standfast for advice and encouragement.

\section{REFERENCES}

Cohen, S. M. \& Wheeler, M. W. (1946). Pertussis vaccine prepared with phase-1 cultures grown in fluid medium. Amer. J. publ. Hlth, 36, 371.

Fisher, S. (1948). The behaviour of Haemophilus pertussis in casein hydrolysate broth. Aust. J. exp. Biol. med. Sci. 26, 299.

Gilder, H. \& Granick, S. (1948). Studies on the Haemophilus group of organisms. Quantitative aspects of growth on various porphin compounds. J. gen. Physiol. 31, 103.

Greaves, R. I. N. (1944). Centrifugal vacuum freezing. Its application to the drying of biological materials from the frozen state. Nature, Lond. 153, 485.

Herbert, D. (1949). Studies on the nutrition of Pasteurella pestis, and factors affecting the growth of isolated cells on an agar surface. Brit. J. exp. Path. 30, 509.

Hornibrook, J. W. (1939). Cultivation of phase I $\boldsymbol{H}$. pertussis in a semi-synthetic liquid medium. Publ. Hth Rep., Wash. 54, 1847.

Hornibrook, J. W. (1940). Nicotinic acid as a growth factor for $\boldsymbol{H}$. pertussis. Proc. Soc. exp. Biol., N.Y. 45, 598.

JeBb, W. H. H. \& Tombinson, A. H. (1955). The nutritional requirements of Haemophilus pertussis. J. gen. Microbiol. $13,1$.

KanTORowicz, O. (1951). Shaking apparatus for the aeration of bacterial cultures. J. gen. Microbiol. 5, 951.

Leslie, P. H. \& Gardner, A. D. (1931). The phases of Haemophilus pertussis. J. Hyg., Camb. 31, 423.

Mazloum, H. A. \& Rowley, D. (1955). The growth requirements of Haemophilus pertussis on solid media. J. Path. Bact. 70, 439.

Miles, A. A. \& Misra, S. S. (1938). The estimation of the bactericidal power of the blood. J. Hyg., Camb. 38, 732.

Monod, J. (1949). The growth of bacterial cultures. Annu. Rev. Microbiol. 3, 371.

Pollock, M. R. (1947). The growth of $H$. pertussis on media without blood. Brit. J. exp. Path. 28, 295.

Proom, H. (1955). The minimal nutritional requirements of organisms of the genus Bordetella López. J. gen. Microbiol. 12, 63.

Rimington, C. (1942). Haemoglobinometry. Brit. med. J. i, 177.

RowatT, E. (1955). Amino acid metabolism in the genus Bordetella. J. gen. Microbiol. 13, 552 .

Schramm, E., Moore, S. \& Bigwood, E. J. (1954). Chromatographic determination of cystine as cysteic acid. Biochem. J. 57, 33. 
Sмrrн, J. C. (1939). Higher aliphatic compounds. VIII. Purification of oleic and elaidic acids. Binary systems from oleic, elaidic, palmitic and stearic acids. The technique of low temperature crystallization. J. chem. Soc. p. 974.

Thorp, R. H. (1941). A method for the microestimation of iron in biological materials. Biochem. J. 35, 672.

Worwod, A. J. (1954). The inhibition of bacterial growth by colloidal heavy metal sulphides and by colloidal sulphur. J. gen. Microbiol. 10, 509.

W.H.O. Report (1953). Diphtheria and pertussis vaccination. World Hlth Org. techn. Rep. Ser. no. 61.

(Received 20 February 1957) 